日消外会誌 $14(8): 1213 \sim 1220,1981$ 年

\title{
消化管腫瘍に打悩る超音波診断の意義
}

\begin{tabular}{llllll}
\multicolumn{8}{c}{ 東京女子医科大学消化器病センター } \\
秋本 & 伸 & 村田 & 洋子 & 斎藤 & 明子 \\
野口 & 友義 & 由里 & 樹生 & 済陽 & 高穂 \\
大森 & 尚文 & 浜野 & 恭一 & &
\end{tabular}

\section{ULTRASONOGRAPHY IN GASTROINTESTINAL TUMOR}

\section{Shin AKIMOTO, Yoko MURATA, Akiko SAITO, Tomoyoshi NOGUCHI, Tatsuo YURI, Takaho WATAYO, Naofumi OMORI and Kyoichi HAMANO}

Institute of Gastroenterology, Tokyo Women's Medical School

消化管腫瘍症例に和ける超音波検査の有用性について検討した。腫瘍の描出は消化管壁肥厚の著しい程 容易で周辺低エュー域と中心高ェュー部より成る．部位による差や癌と肉腫での差は認め難かった．朋転 移診断率は $87 \%$ で撒布性小転移の診断は困難であった。音響陰影を伴う高エコーレベルの肝転移像は大腸 癌に特徵的であった．転移リンパ節は直径 $3 \mathrm{~mm}$ 以上で描出可能であった．大腸癌局所浸潤の間接所見と して水腎症の診断が有効であった．直腸癌術後骨盤内再発は膀胱の変形と腫瘍像から䛦断可能な例むあっ たが瘫痕組織との判別が困難であった。

索引用語：超音波検査, “消化管腫瘟、肝移転, リンパ節移転, 尿路浸潤

はじめに

第 1 次世界大戦で海底探查や潜水艦探知の目的で実地 に利用された超音波が初めて医学に応用されたのは 1942

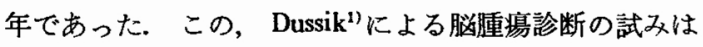
成功せず，幾多の困難な問題の解決を経てのちようやく 1960年代に入って, 主として心葴と産科領域で臨床使用 されるに至つた，一方消化器領域で超音波検查が十分な 診断能を持つに至ったのは1970年代に入ってからと言っ てよからう。そして今日では肝腈胆道系に批ける不可久 な診断法の1つとして認識されるまでになったが，消化 管疾患における超音波診断の意義は一般に薄いとされて いる. しかし近年診断機器の改良が進み, 超音波検査が 消化器スクリーニング検査法として頻用されるようにな るに従い，消化管腫瘍の超音波像を正しく理解すること は意味あることであり，さらにその転移再発における有 力な情報源として，超音波診断の占める位置は必ずしも 低いものではないと考えている，この観点から，消化管 悪性腫瘍患者を対象にわれわれが行った超音波検査成績 並びに検查所見について検討した.

\section{装置および方法}

主な使用装置は，手動接触複合走查装置としては，東 芝 SSL-51C（スキャンコンバーター付， $2 \cdot 3.5 \mathrm{MHz} 10$ $\mathrm{mm} \phi$ 约面探触子）を用い, 又実時間表示装置としては, 東芝 SAL-20A ( $3.5 \mathrm{MHz}$ リニア電子スキャン)を用い た.

検查体位は坐位および仰臥位を原則とし，必要に応じ て半坐位, 半側臥位にて施行した. 検查前処置は行わ ず，脺胆道系検查を併せ行 5時にのみ絶食検查とした。 骨艋内腫瘍の検索に際しては排尿を我慢させ膀胧の充満 を図った。

\section{対 象}

検査対象は1974年 1 月から1980年 6 月までに東京女子 医大消化器病センターで超音波検查を行った約7,000症 例（検査延べ13，107回）のらち手術で確定診断された上 部および下部消化管腫瘍患者である. 原発腫瘍病巣につ いては超音波検查で発見した12症例の所見を中心に検討 を行い，肝転移については超音波所見と組織所見を対比 検討するため検査後 2 週間以内に肝合併切除を行った 15 
症例を中心に検討した、リンパ節転移に関しては上部消 化管腫崵39例の郭清リンパ節の組織所見と超音波所見を 対比し, さらに直腸癌局所再発症例10例について子検討 を加えた。

\section{消化管腈要觡断について}

正常消化管のうち最も容易かつ鮮明に描出されるのは 胃幽門前庭部である.これは，この部の胃壁が厚く，通 常空気を含をないためと考えられる（図1）。

\section{图 1 胃前庭部正常超音波像}
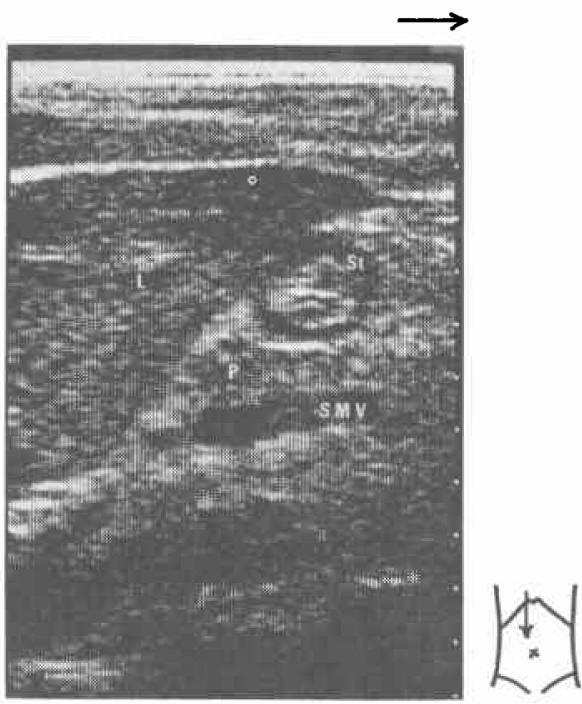

( $\mathrm{L}$ : 肝左葉, $\mathrm{St}$ : 胃, $\mathrm{P}$ : 膵, $\mathrm{SMV}$ : 上腸間膜静 脈）胃辺縁部無エコー帯は胃壁を, 内部ェコーは内 腔を意味する。

表 1 超音波検査で発見した消化管悪性腫瘍

\begin{tabular}{|c|c|c|}
\hline 部＼cjkstart位 & 腫 演 & 例 数 \\
\hline \multirow{2}{*}{ 胃 } & 癌 & 3 \\
\hline & 肉腫 & 1 \\
\hline 十二指腸 & 肉腫 & 1 \\
\hline 空 腸 & 肉腫 & 1 \\
\hline \multirow{2}{*}{ 結＼cjkstart腸 } & 癌 & 5 \\
\hline & 肉腫 & 1 \\
\hline \multicolumn{2}{|c|}{ 計 } & 12 \\
\hline
\end{tabular}

尰瘍の場合も壁の肥厚が著しい程その描出は容易とな る. 全検査回数13,107回のらち全周乃至全周に近い壁肥 厚を示す消化管腫瘍の検査は150回であった。このうち 12例をスクリーニング超音波検査で発見した（表１）.
図 2 Borr IV型胃癌

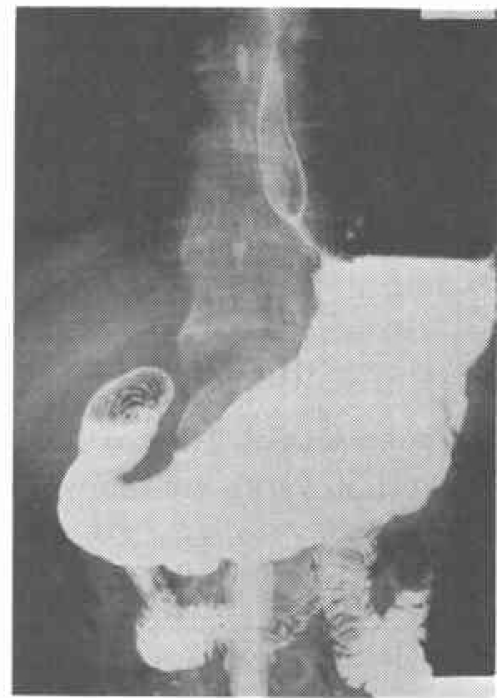

図3図2 と同一症例の超音波像

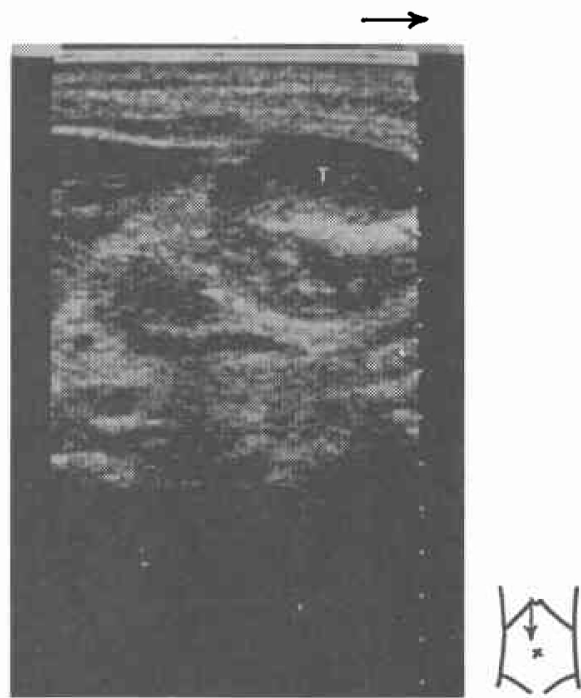

（ T：腫場）胃壁の肥厚が著しい。

その典型的な像はスキルス型胃癌 (図2,3) や全周性 狭窄の著しい結腸癌（図 4,5) でみられる. 周辺低エ コーレベル帯は壁の腫煌性肥厚を示し, 中心近くのやや 不整形の強いェューは内腔に相当し, 通常強い音響陰影 を伴うものである.一見, 腎臓の超音波像に似た形態を 示すのがその特徽である.

腫瘍発生部位による差異は認め難く，胃，十二指腸 小腸, 大腸いずれの部の悪性腫瘍でもその超音波像は類 
図 4 盲腸上行結腸癌

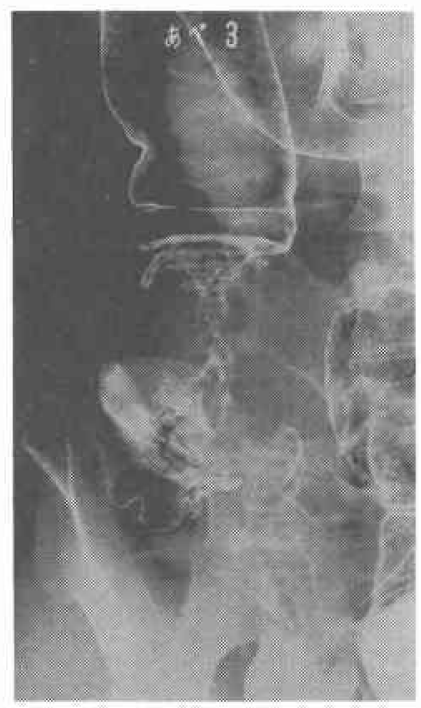

図 5 図4 と同一症例の超音波像
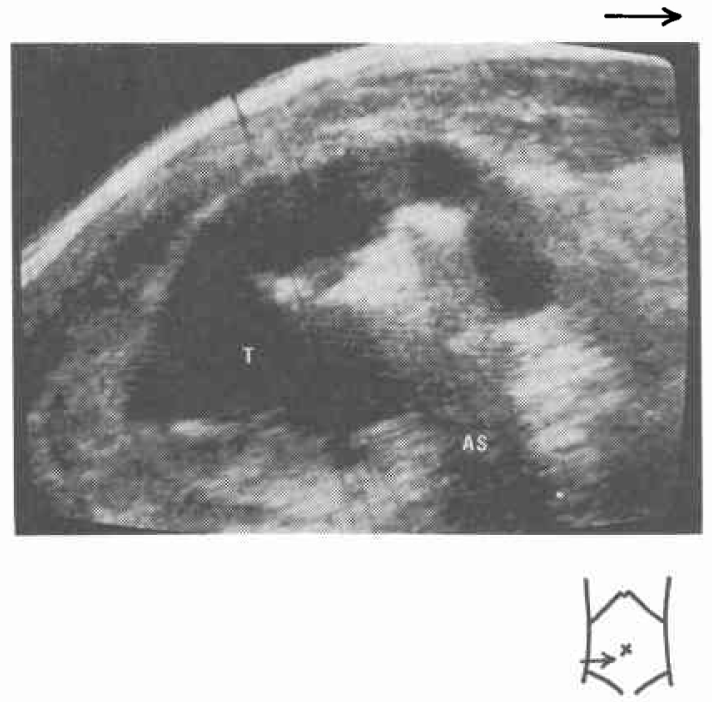

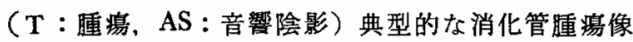
で、凹凸のある壁肥厚像と，音響陰影を伴ら強い内 腔エコーがみられる。

似して招り，また癌と肉腫の差異も殆ど誌められず同様 の基本像を呈する. 腫瘍内部に不整エコーを認めること は少く, ある程度以上の大きさになるとしばしば内部不 整エコーを伴ら肝膵腫瘍とは際立った相違を示した.こ れは消化管腫瘍内の音響組織学的均一性を意味するむの と考えられる. 稀れに内部不整エューを示した例は, 壁
外性発育の著しい大さな肉腫などでみられた腫瘍内多発 壊死巣の存在によるものであった（図6，7).

鑑別すべき超音波像を呈したのは腸管周囲の炎症性变 化であった，すなわち憩室炎，虫垂炎等に起因する膿瘍 や，稀れなものとしては腸管周辺の肉芽腫などである (図8).これらはいずれも不整形で内腔を意味する明 瞭な中心ェューおよび音晦陰影を欠くことから典型的な 消化管腫痬像とは異り, 鑑別可能であった.

肝転移診断について

肝転移診断は，消化管腫瘍に対して超音波検查が最も

図 6 十二指腸肉腫の超音波像

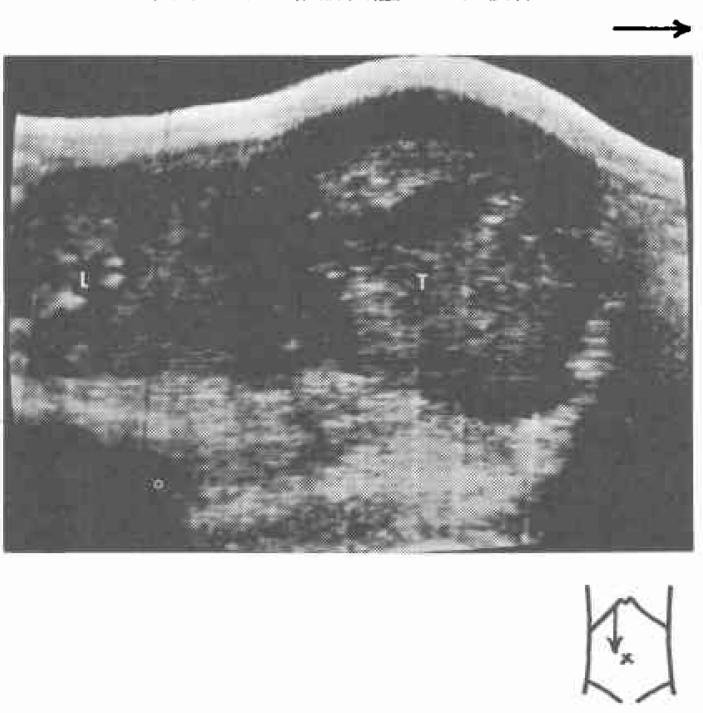

( $\mathrm{L}:$ 肝, $\mathrm{T}:$ 腫瘍) 肝下面に接して大さな腫瘍像 がみられる。内部は強いェコーやぬけなど、いわゆ る mixed pattern を呈する。

図 7 図 6 と同一症例の切除標本

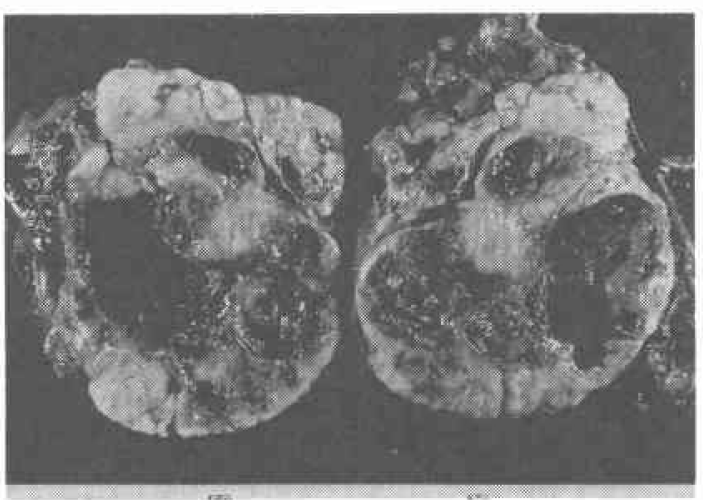


図 8 非特異性回腸潰煌周囲の肉芽腫超音波像
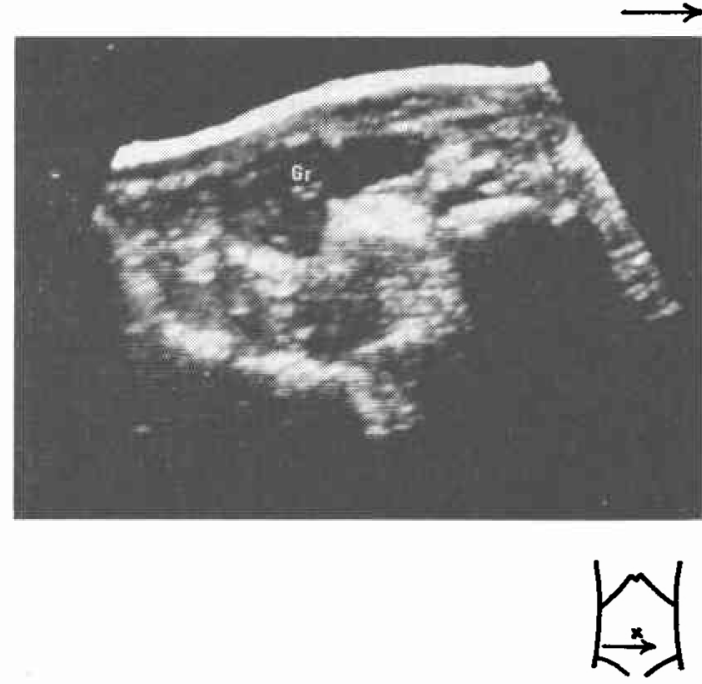

（Gr：肉芽腫）全体に不整形のぬけを呈し、音整陰 影を伴う内腔ェコーはみられない.

寄与し得る領域であろら ${ }^{2)}$. 東京女子医大消化器病セン ターに护ける，超音波検査による肝転移（肝内睡湯）診 断率は，約87\% (52/60) である。なお false positive は $0.6 \%$ と少なかった. false negative 8 例を検討すると， 初心者による見落しと，多発撒布性転移例の見落しであ った。

肝内腫瘍の超音波診断は，非腫瘍部との音響インピー ダンスの差によるエコーレベルの違い，扣よび腫瘍内部 エコーパターンの認識によりなされる゙). 固有音響イン ピーダンスが周辺非腫瘍部と異り，高エコーレベルある いは低ェコーレベルを示す場合（図9）は診断が容易で あった.しかし非腫瘍部とェコーレベルが近いものや， 直径 $1.5 \mathrm{~cm}$ 程度以下の撤布性小転移の診断は難しく, ことに肝表面にみられる平坦な形の転移巣では見落し易 いため注意深い観察が必要であった。

\section{リンパ莭転移診断について}

手術時摘出腹腔内リンパ節（39例63ב）の検討から, 㨁径 $3 \mathrm{~mm}$ 以上の転移リンパ節は描出が可能であった が, 腫演細胞がリンパ節の一部のみを占拠している場合 は㨁径 $1.5 \mathrm{~cm}$ 以下のものの超音波描出能は不良であっ た. 診断率は $58.7 \%$ で大きさ別診断能は以下の如くであ った.すなわち $4 \mathrm{~mm}$ 以下では2/11 (18.2\%), 5〜9mm で6/16 (37.5\%), 10〜19mm で21/27 (77.8\%), 20mm 以上で $8 / 9(88.9 \%)$. しかし腸管や脂肪組織などによ
図 9 胃癌肝転移超音波像

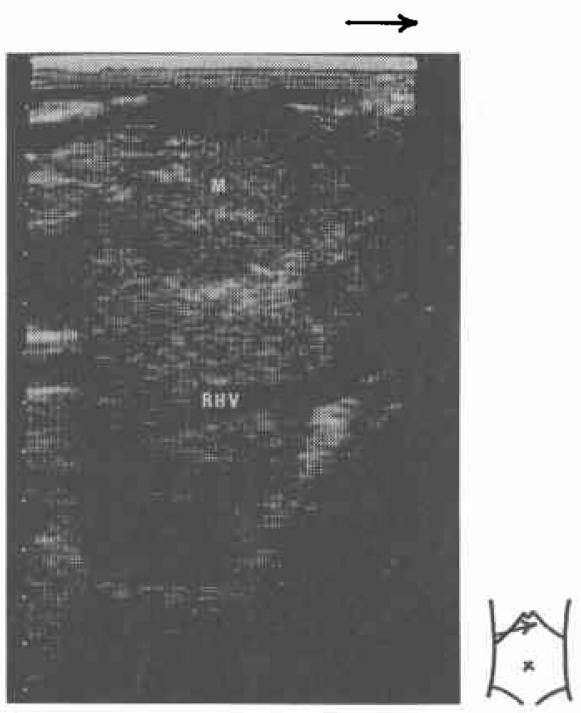

（M：転移巣, RHV：右肝静脈）転移巣は低ェコー レベルを示し、境界明瞭である。

り，部位によっては観察が困難であり，リンパ節の部 位診断は胃肝脺脾, 大動脈とその分枝, 門脈など, land mark となる䁍器や脈管との位置関係が画像上確認でき るもの以外は不正確であった.

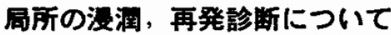

超音波検查が関与し得るもう1つの領域が結腸直腸癌 等の局所浸潤診断である. 局所浸潤を直接に描出するこ とは困難であるが，浸潤により尿路狭窄が生ずる場合は 水腎症を描出することにより間接的に局所漫潤を推測す ることが可能であった. 水腎症の診断は超音波診断のう ち最も判定の容易なものの 1 つであり，腎実質と拡張腎 而腎杯の双方がともに鮮明に捉えられ（図10), 経静脈 的腎血造影よりる確実に判定できる. Schnitzler 転移の らちのあるるのでは, 片側あるいは両側の水腎症を来す ことがあり，これも同様に超音波検查による間接的診断 の助けとなり得た. したがって消化管腫瘍例における超 音波肝転移検查に際しては, 肝葴とともに両側腎缄の検 索を行らことが甚だ重要であった。

直腸癌の術後骨盤内局所再発についても, 膀胼が腫瘍 により王排を受けると超音波像から診断可能な例があっ た (図11). しかし術後症痕組織との鑑別が難しく, い ずれの症例もくり返し検査により経過を追って大きさの 変化をみる必要があった（表 2 ）. 
国10 水督症超音波像
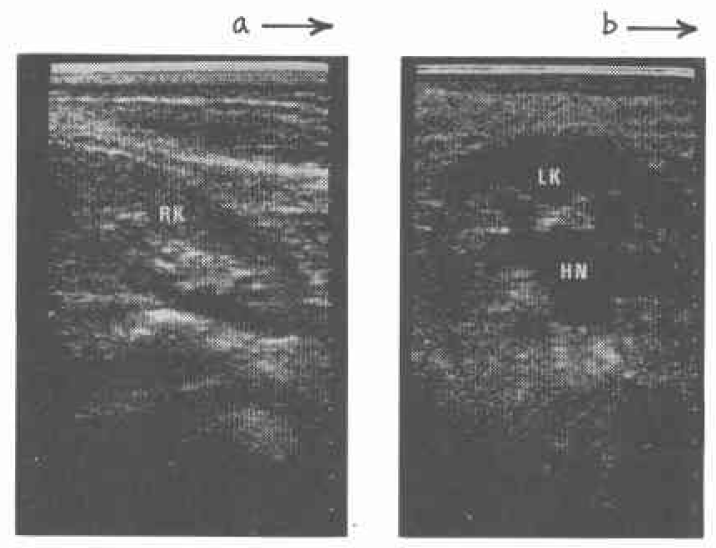

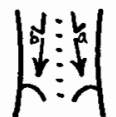

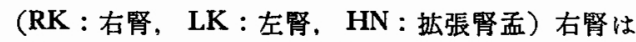
正常像，左腎は直腸癌の左尿管下部浸蘭㲌年水腎 症の像.

図11 直渴癌局所再発超音波像

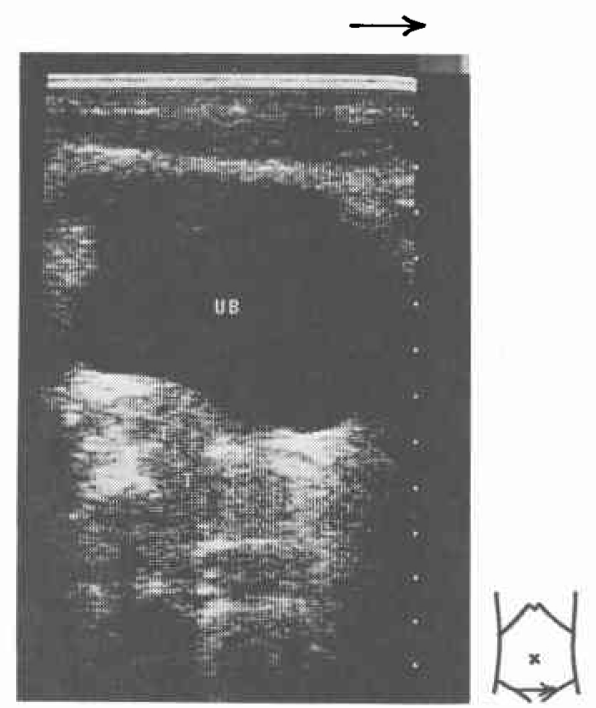

(UB：膀脱, $\mathrm{T}:$ 腫瘍) 腹会陰式直腸切断術後の

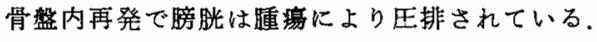

\section{考察}

消化管腫瘍の超音波診断に関しては，これまでに胃癌 についての報告等を僅かにみるに過ざない(45)6)。また， 消化管内腔加行う超音波検査に関しても, 食道内腚か
表 2 直腸癌局所再発診断

\begin{tabular}{l|c|c|c}
\hline \hline & 施行例数 & 局所㟝断 & 水腎症診断 \\
\hline 血管造影検查 & 5 & 4 & \\
\hline C T 検查 & 4 & 2 & \\
\hline 超音波検查 & 10 & 2 & 3 \\
\hline
\end{tabular}

らの心蔵診断や，胃を介しての搭葴診断，経直腸的前立 腺診断”，などがあるに過ざない，消化管小病変につい ては，通常超音波検査の対象外であるが，たと兊ば水で 胃を充満させることにより早期胃癌を超音波画像として 描出することなども可能である. しかしX線検査，内視 鏡検査の進歩著しい今日，いわゆる早期癌，微小癌の誩 断や発見に超音波検查が関与することはほとんどない。 本検查法が消化管睡瘍の診断に寄与し得るのは，まづ第 1 亿腹部腫瘤の鑑別における first choice 検查としてで あろう. 触診で発生臟器不明の腫瘤を認めた際, 超音波 検査によって消化管由来か否かを判定することは，その 後の検查計画を無䭾なく進める上で意味あることである う.ことに大腸腫湟では完全閉塞を来すまで便通異常や 腸閉塞症状を呈さ炕とが多く, $\mathbf{X}$ 線検査や内視鏡検査 が遅れることもあり，このような症例に超音波検查で的 確に腫瘍由来藏器の判定を下すことはより早い時期に外 科的処置を加兄得るとい5点から有意義と考兄られる.

本検查が寄与し得る第 2 の点は腫瘍の術前, 術中, 術 後のそれぞれに和ける肝転移猃断である。そのそれぞれ に怙ける意義を以下に記すと，

(1) 術前検査として

本検查は無侵襲であり造影剤を用いず同時に広範囲 多臓器の倹索が可能であり, 畽場の遠隔転移状況の把握 にすぐれている.とくに肝転移に関しては正常肝内構築 の乱れとェコーレベルのムラに注目しつつ実時間表示装 置で肝内を動態観察するとその診断は比較的容易であ る. 術前に肝転移のないことを確認するのは勿論, 肝転 移があっても合併切除の可能性を判定することも重要で ある. とくに大腸癌では肝転移巣が限局性の場合, 合併 切除による長期生存例る報告されており, 血管造影検査 とあわせて, より的確な立体的位置把握が必要であろ う. 超音波所見からは転移巣と肝内静脈門脈を同時に明 瞭に観察し得ることから合併切除を考慮に入れた術前肝 転移診断法として本娭查法は有力なるのと言兄よう。

（2）術中検查として

術前検查で死角となり易い朋右葉上部横隔膜直下の検 
索や，術中に視診触診で肝に異常を認めた際などに探触 子を直接肝表面にあてて術中検查を行うことは有用であ る. とくに肝転移がある場合，切除範囲を術中に決定す る上でいわば肝内を直視下に立体的に把握することが可 能な術中超音波検查は有力な情報を与えてくれるむので ある.われわれは術中超音波画像をガイドにした肝切除 法を開発し ${ }^{8)}$ ，現在までに消化管腫瘍の肝転移合併切除 例17例中 5 例に本法を施行している（表 3）。な扰中 検査にはわれわれの考案した薄型穿刺溝付探触子の使用 が有効である(図12，13）。また幕内ら ${ }^{9}$ 小小型の術中 用探触子を発表している.

（3）術後検查として

術後転移再発を早期に発見することは，これに治療を 加えて予後を良好ならしめる上で重要なことである。わ れわれは術後, 生化学的検查, 血清 CEA 值測定と共に 定期的頻回の超音波検查を行っており，このようにして 発見した術後肝転移，さらには転移肝切除後再転移に対 して，肝切除を行い良好な結果を得ている ${ }^{10)}$.

\section{表 3 肝転移合併切除症例}

\begin{tabular}{c|c|c}
\hline \hline 原疾患 & 肝転移切除例数 & $\begin{array}{c}\text { 超音波ガイド } \\
\text { 切除 例 }\end{array}$ \\
\hline 胃 癌 & 4 & \\
\hline 胃肉腫 & 1 & \\
\hline 結腸癌 & 7 & 1 \\
\hline 直腸癌 & 5 & 4 \\
\hline 計 & 17 & 5 \\
\hline
\end{tabular}

図12 術中検査用穿刺溝付超音波操触子

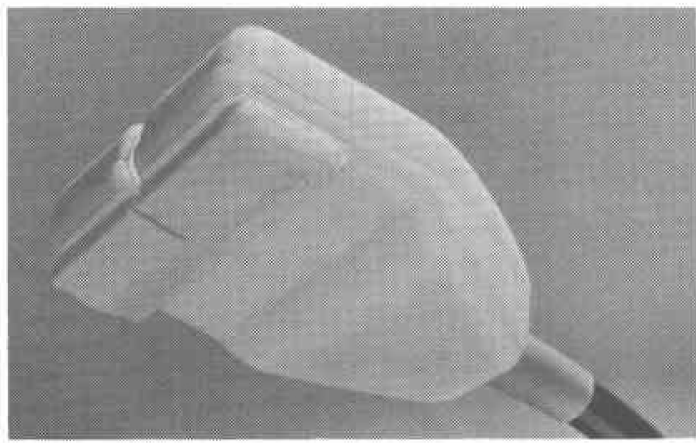

探触子は薄型で，超音波は先端から直角方向（写真 の下方向）に放射される、術中，肝へ直接，あるい は体表からの穿刺のためにV字型に切りこんだ穿刺 溝を設けてある。
図13術中超音波検査による肝転移検索

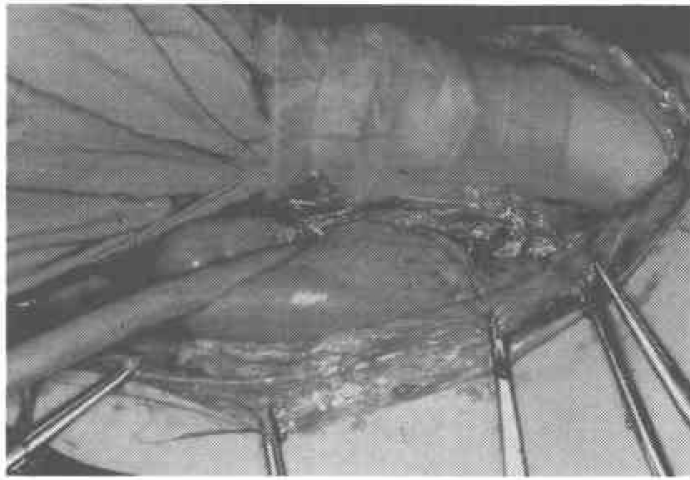

探触子が薄型であるため下腹部手術創からでも，ほ ほ肝全域の検索が可能である。

図14 直腸癌肝転移超音波像
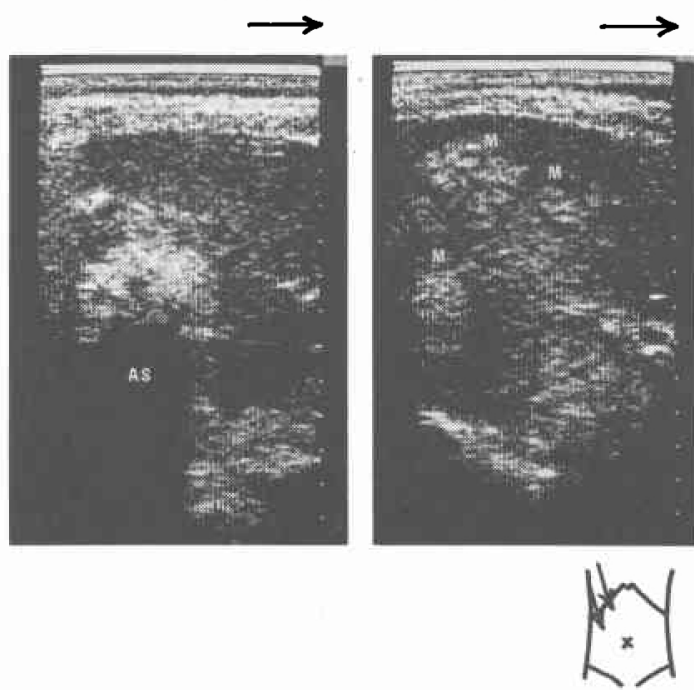

( $\mathrm{M}$ : 転移巣, $\mathrm{AS}$ : 音铃陰影) 右葉に多発転移巣を みとめるが，個々の転移巣は様々の形態とエコーレ ベルを示す。

肝転移に特有な超音波像はなく，基本的には原発性肝 癌と同様のいわゆる腫漡エコー像を呈する. しかし多発 性でそれぞれの大きさ，形態，内部エコーに統一性がみ られない例では転移性肝尰瘍之診断乙得る(図14). 原 発藏器による差異もまた明らかではないが，消化管腫場 のうち大腸癌の肝転移像は高エューレベルのものが多く みられ，その約 $7 \%$ には音響陰影を伴う程の強いエュー を示すむのるみられる(図15).この特徽ある強いエ 
図15 結腸癌肝転移超音波像

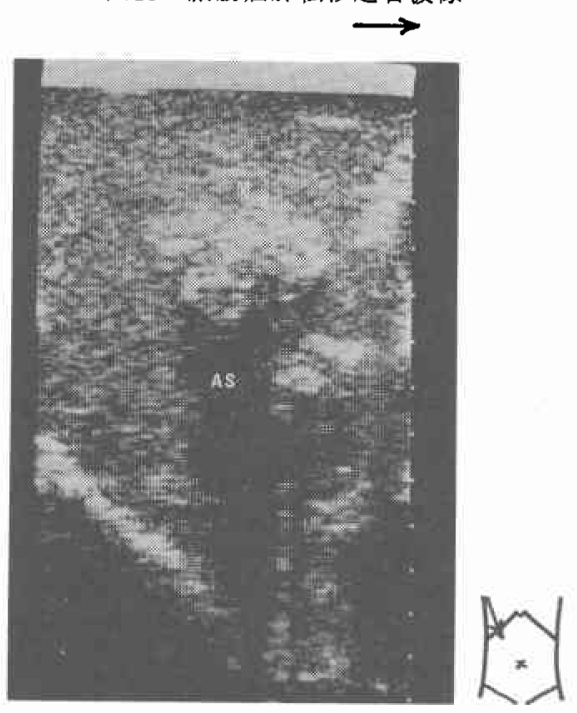

（M：転移巣， AS : 音響陰影） $\mathrm{S}$ 状結腸癌転移巣 で、明瞙な音響陰影を伴う特徴的な強いメコー像を 示す。

コーは組織所見の検討から, 転移巣内の豊富な線維成分 と微小壊死巣の散在，ムチン様物質の存在に起因するこ とが推定されるが，このような病理組織所見は, 原発性 肝癌や上部消化管腫瘍肝転移の組織には認め難いもので ある(図16).

図16 図!5と同一察例の切除䅺本ルーベ像

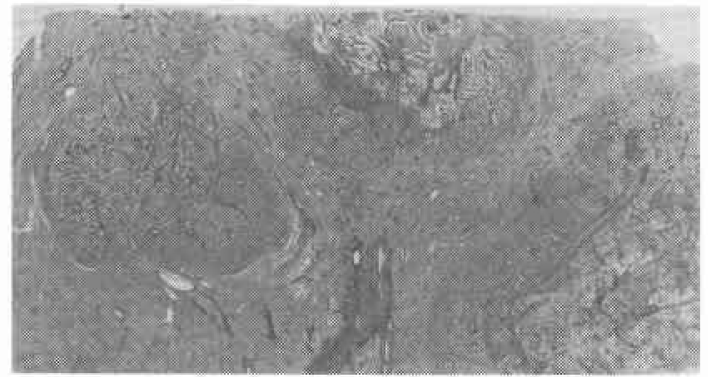

合併切除した肝転移巣のルーぺ像で，島状の腫瘍細 胞塊と, 豊富な結合織成分, 壊死巣，ムチン様物質 の混在がみとめられる。

肝転移巣が小さい場合はスキャンでのとびこしによる み扣としが起こり得る訳であるが，実時間表示が可能な (すなわち動態観察が可能な) 装置の実用化に伴い連続 的な観察が行えるようになり、このようないとびこしエ
ラー”は解消されたと言ってよかろ5，また周囲とエ コーレベル差の少ない転移巣についても動態観察によっ て病変の拾い上げが容易になった。非腫瘍部分のいわば background echo と, 腫瘍内のエコーパターンが異り, 動さの中で捉えるとその違いが明瞭に認識されるためで ある.これは脈管を主とした微細組織構築の違いに起因 する，腫瘍と非腫瘍部分のエコーパターンの相違による ものと考えられる，われわれの超音波検查による肝転移 診断率は約 $87 \%$ でこれは血管造影検查に扣ける診断率 （約90\%）に匹敵するものである. 無侵暜検查であるこ とから，くり返し検查（とくに術後の follow upなど） に対する超音波検查の有効性は明らかである。なお RI シンチグラフィーの肝転移診断率は約 $60 \%$ であるが，転 移の部位と大きさで診断率が大きく異る.

最近の装置の進歩による解像度の向上や実時間表示 は，從来捉えることの難しかったリンパ節転移もある程 度超音波像として描出することを可能にしたと言ってよ かろら，とりわけ，大動脈とその分枝，上晹間膜静脈と 門脈, 下大静脈, 肝下面, 膵などの近傍のものは球形の エューのぬけとして諗識し易い. りンパ節と脈管断面と の鑑別が問題となるが，実時間表示装置での動態観察に より，脈管はその連続性が追及できるので，慎重に観察 しさえすれば判定は困難ではない.しかしながらリンパ

図17 転移リンパ節超音波像

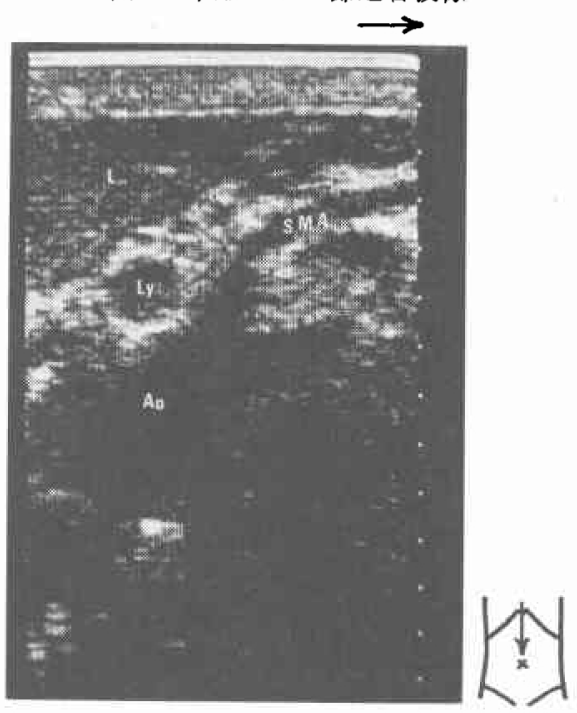

（L：肝、 Ly：リンパ節, SMA : 上腸間膜動脈, Ao: 大動脈）胃癌のリンパ節転移像で，腹腔動脈幹 根部近くに明瞭な球形のぬけとして捉えられている。 
節がどの程度腫場細胞に占拠されると超音波像上認識可 能となるのか，また炎症性腫大を起こしたリンパ節が転 移リンパ節様にぬけて描出されることはないのかな ぞ false negative や false poistive の点で今後検討を要 する点が多く残されている.これらの問題が解決されれ ば，消化管腫瘍の術前把握の面で超音波検查が果す役割 はさらに増すと言えよう（図17）。

腫瘍の尿路系狭窄による水堅症の発見は主として盲 腸, $\mathrm{S}$ 状結腸, 直腸における腫暘の局所進展や術後局所 再発の間接所見と言えよう。これらに関しては従来的確 な診断法がなく, 最近の CT 検査の進歩によっても骨 盤内局所再発に関しては未だ十分な成績が得られていな いところから，超音波検査によるこれらの所見の把握は 意味あるものと考光られる.

\section{おわりに}

最近, 超音波検查は診断能が向上し腹部消化器領域に おいても急速に注目されるに至った. われわれは過去 7 年間に約13,000回の腹部超音波断層検查を行ってきた が，従来言われてきた肝脺胆道系に対する診断価値にと どまらず，消化管腫瘍に対しても診断的意義を有するむ のと考えるに至った. 寸なわら, 腹部腫䒇の鑑別や，肝 転移,リンパ節転移, 局所浸潤に対する術前・術中・術 後における有意義な検查手段であると評価し得るもので ある. さらに管控内超音波探触子の改良や, 内視鏡的超 音波装置の開発等を通じて，消化管腫䁑の深達方向への
浸潤の診断や粘膜下腫瘤の性状診断などへの超音波検査 の応用が期待される.

\section{文献}

1) Dussik, K.T.: Uber die Möglichkeit, hochfrequente mechanische Schwingungen als diagnostisches Hifsmittel zu verwerden. Z. Ges. Neurol. Psychiatr., 174: 153—168, 1942.

2) 福田守道ほか：肝・胆・膵超音波診断の実際. 89 - 91 , 金原出版, 東京, 1979 .

3) 井出正男ほか：超音波診断法，5一6，電波実験 社, 東京, 1973 .

4) 小林利次浪：管腔贜器癌の超音波断層像。超 音波医学, 3：110-112，1976.

5) Walls, W.J.: The evaluation of malignant gastric neoplasms by ultrasonic B-scanning. Radiology, 118: 159-163, 1976.

6) Kremer, $H$. et al: Sonographische Diagnostik bei infiltrativen Magen-Darm-Erkrankungen. Dtsch. Med. Wschr., 103: 965—966, 1978.

7) 褀橋善克ほか：泌尿器科領域における超音波猃 断の現況。超音波医学, 3：191-200，1976.

8) 秋本 伸ほか：術中超音波検査一䏕硬変合併小 肝癌切除に捕ける有用性について。外科, 42 : $189-194,1980$.

9）幕内雅敏ほか：新たに開発した術中超音波唡査 用探触子。映像情報，11：1167-1169, 1979 .

10) 由里樹生ほか：大腸癌肝転移症例に対する治 療。日消外会誌, 13：232-237, 1980 . 